\title{
RENTABILITAS EKONOMI PD. BPR PK ARAHAN: PENGARUH HUTANG TERHADAP KREDIT
}

\author{
Economic Rentability at PD. BPR PK Arahan: Effects of Debt on Credit
}

\author{
Chairunisa Cipta, Daryono Setiadi, Samsul Anwar \\ Manajemen FE Unwir \\ daryonofe@gmail.com, anwar_909@yahoo.com
}

\section{ABSTRAK}

Pengaruh Hutang Terhadap Rentabilitas Ekonomi Melalui Kredit pada PD. BPR PK Arahan, Kondisi hutang pada PD. BPR PK Arahan selama 6 tahun dari tahun 2012 - 2017 mengalami penurunan pada tahun 2013 sebesar $(-0,5 \%)$ dan 2014 sebesar (8,3\%), sedangkan pada tahun 2015 - 2017 mengalami peningkatan yang cukup besar, tahun 2015 meningkat sebesar 28,9\%, tahun 2016 sebesar $50 \%$ dan tahun 2017 sebesar 79,1\%. Kondisi kredit pada PD. BPR PK Arahan selama 6 tahun dari tahun 2012 - 2017 cenderung mengalami peningkatan pada tahun 2017 sebesar 74,1\%, dan mengalami penurunan hanya pada tahun 2014 sebesar (-2,5\%). Kondisi rentabilitas ekonomi pada PD. BPR PK Arahan selama 6 tahun dari tahun 2012 - 2017 cenderung mengalami penurunan, dan mengalami peningkatan hanya pada tahun 2015 sebesar (13981,4\%). Hutang berpengaruh signifikan terhadap kredit pada PD. BPR PK Arahan. Berdasarkan hasil uji statistik koefisien korelasi product moment pearson di peroleh $\mathbf{r}=$ 0,999 yaitu korelasi yang sangat kuat dan positif. Koefisien determinasi $\mathrm{Kd}=\mathbf{9 9 , 8 \%}$ yang berarti hutang memberikan pengaruh terhadap kredit pada PD. BPR PK Arahan sebesar 99,8\%, sedangkan sisanya yang $0,2 \%$ dipengaruhi oleh faktor-faktor lain yang tidak diteliti. Uji regresi linear sederhana diperoleh $\mathrm{Y}=\mathbf{0 , 1 8}+\mathbf{0 , 9 8} \mathrm{X}$ yang artinya bila nilai hutang bertambah 1 maka nilai kredit akan naik sebesar 0,98. Uji hipotesis diperoleh thitung $=44,4$ dengan ttabel pada $\alpha=$ $20 \%$ adalah 4,032 , sehingga nilai thitung $>$ ttabel $(44,4>4,032)$, yang berarti Ho ditolak dan Ha diterima maka hutang berpengaruh signifikan terhadap kredit, dengan demikian hipotesis yang diajukan diterima.

Kredit tidak berpengaruh signifikan terhadap rentabilitas ekonomi. Berdasarkan hasil uji statistik koefisien korelasi product moment pearson di peroleh $r=0,219$ yaitu korelasi yang rendah dan positif. Koefisien determinasi Kd = 4,7\% yang berarti kredit memberikan pengaruh terhadap rentabilitas ekonomi pada PD. BPR PK Arahan sebesar 4,7\%, sedangkan sisanya 95,3\% dipengaruhi oleh faktor-faktor lain yang tidak
\end{abstract}

diteliti. Uji regresi linear sederhana diperoleh $\mathbf{Y}=$ $0,01+0,00018 \times$ yang artinya bila nilai kredit bertambah 1 maka nilai rentabilitas ekonomi akan naik sebesar 0,00018. Uji hipotesis diperoleh thitung $=0,460$ dengan ttabel pada $\alpha=50 \%$ adalah 0,727 sehingga nilai thitung $>$ ttabel

$(0,460>0,727)$, yang berarti Ho diterima dan Ha ditolak maka kredit tidak berpengaruh signifikan terhadap rentabilitas ekonomi, dengan demikian hipotesis yang diajukan ditolak.

Kata Kunci: Hutang, Kredit, Rentabilitas Ekonomi.

\section{ABSTRACT}

Debt conditions for PD. Referral PK BPR for 6 years from 2012 - 2017 decreased in 2013 by ($0.5 \%)$ and 2014 amounted to $(-8.3 \%)$, while in 2015 - 2017 there was a substantial increase, 2015 increased $28.9 \%, 2016$ amounted to $50 \%$ and 2017 amounted to $79.1 \%$. Credit conditions at PD. Referral PK BPR for 6 years from 2012 - 2017 tended to increase in 2017 by $74.1 \%$, and decreased only in 2014 by $(-2.5 \%)$. Conditions of economic rentability in PD. Referral PK BPR for 6 years from 2012 - 2017 tended to decrease, and only increased in 2015 by $(13981.4 \%)$. Debt has a significant effect on credit in PD. BPR PK Referrals. Based on the results of the statistical test the product moment Pearson correlation coefficient obtained $\mathbf{r}=0.999$, which is a very strong and positive correlation. The coefficient of determination $\mathrm{Kd}=\mathbf{9 9 . 8 \%}$ which means that debt has an influence on credit in PD. Referral PK BPR is $99.8 \%$, while the remaining $0.2 \%$ is influenced by other factors not examined. Simple linear regression test obtained $\mathrm{Y}=0.18+0.98 \mathrm{X}$, which means that if the value of debt increases by 1 then the credit value will increase by 0.98 . Hypothesis testing obtained thitung $=\mathbf{4 4 . 4}$ with $\mathrm{t}$ table at $\mathrm{a}=$ $20 \%$ is 4.032 , so the value of tcount $>t$ table (44.4> 4,032), which means $\mathrm{Ho}$ is rejected and $\mathrm{Ha}$ is accepted, the debt has a significant effect on credit, thus the proposed hypothesis is accepted. 
Chairunisa Cipta, Daryoni dan Samsul Anwar

Credit does not have a significant effect on economic rentability. Based on the results of statistical tests the product moment Pearson correlation coefficient was obtained $r=0.219$, which is a low and positive correlation. The coefficient of determination $\mathrm{Kd}=4.7 \%$, which means that credit has an effect on economic rentability in PD. Referral PK BPR of 4.7\%, while the remaining $95.3 \%$ is influenced by other factors not examined. Simple linear regression test obtained $Y=0.01+0,00018 \mathrm{X}$, which means that if the credit value increases 1 , the value of economic rentability will increase by 0,00018 . Hypothesis testing is obtained thitung $=\mathbf{0 . 4 6 0}$ with $\mathrm{t}$ table at a $=50 \%$ is 0.727 so the value of tcount $>t$ table (0.460> 0.727), which means that $\mathrm{Ho}$ is accepted and $\mathrm{Ha}$ is rejected, the credit does not have a significant effect on economic rentability, thus the proposed hypothesis is rejected.

Key Words: Debt, Credit, Economic Rentability.

\section{PENDAHULUAN}

Di sektor keuangan, terdapat lembagalembaga keuangan yang mendukung dan memiliki peran dalam memajukan perekonomian bangsa. Salah satu lembaga keuangan yang memiliki peran dalam memajukan perekonomian bangsa adalah perbankan. Bank mempunyai peran memobilisasi dana masyarakat dengan menghimpun dana dari masyarakat dan menyalurkannya kembali ke masyarakat yang membutuhkannya dalam bentuk pinjaman atau kredit. Manfaat dari pemberian kredit ini, masyarakat diharapkan mampu meningkatkan taraf kehidupan dan kesejahteraannya.

Bank memiliki peran dalam menghimpun dana dari masyarakat dan menyalurkannya kembali kepada masyarakat yang membutuhkan. Dana yang dihimpun oleh bank dialokasikan ke dalam berbagai aktiva, baik yang produktif maupun yang tidak produktif. Bagian terbesar dari penyaluran dana tersebut ke dalam aktiva produktif adalah pinjaman atau kredit. Tujuannya adalah agar mencapai tingkat pendapatan yang optimal dengan tetap memelihara tingkat likuiditas yang sehat.

Dana yang diperoleh bank identik dengan hutang, karena sumber dana bank dapat berasal dari sumber eksternal yaitu lembaga keuangan (dana pihak kedua) maupun dana dari masyarakat (dana pihak ketiga). Sesuai dengan fungsinya sebagai lembaga keuangan yang kegiatan sehariharinya tidak terlepas dari bidang keuangan. Karena untuk menopang kegiatan bank sebagai penjual uang (memberikan pinjaman), bank harus lebih dulu membeli uang (menghimpun dana) sehingga dari selisih bunga tersebut bank memperoleh keuntungan.

Dana masyarakat yang terhimpun oleh bank merupakan dana titipan yang menjadi hutang bagi bank, karena bank mempunyai kewajiban untuk membayar kembali pada saat jatuh tempo atau sewaktu-waktu diambil. Untuk memperoleh dana masyarakat tersebut, bank menawarkan berbagai bentuk simpanan baik deposito maupun tabungan. Sumber dana masyarakat ini sangat penting bagi bank dan menjadi sumber dana utama bank karena dana masyarakat tersedia cukup banyak dan mudah mendapatkannya. 
Chairunisa Cipta, Daryono dan Samsul Anwar

Disamping itu hutang pada bank dapat bersumber dari pihak luar yaitu lembaga keuangan. Hal ini biasanya dilakukan apabila bank mengalami kesulitan atau kekurangan dana yang tidak bisa ditutupi oleh dana pihak pertama maupun dana pihak ketiga. Hutang pada pihak luar disebut juga dana pihak kedua yang bersifat sementara dan berbiaya cukup mahal.

Semakin besar dana yang dihimpun bank dari hutang menunjukkan bank memiliki kemampuan untuk memberikan pinjaman/kredit yang besar pula. Ini berarti akan semakin besar pendapatan yang akan diperoleh, namun jumlah pendapatan bank yang besar belum menjamin menciptakan laba yang besar pula apabila dana yang digunakan tersebut biayanya mahal. Akibatnya bank memiliki kewajiban yang besar terhadap dana yang dihimpun tersebut dan perolehan laba akan semakin rendah.

Secara teoritis semakin besar dana yang dapat dihimpun bank, semakin besar kredit yang dapat diberikan dan semakin besar pula kemungkinan memperoleh pendapatan. Namun dalam realisasinya tidak semudah itu karena manajemen harus memperhatikan berbagai aturan yang dikaitkan dengan penilaian kesehatan bank. Karena selain memberikan keuntungan, pemberian kredit juga mengandung resiko terhadap hilangnya dana akibat kredit bermasalah atau macet.
Hal ini akan mempengaruhi terhadap tingkat kemampuan dalam memperoleh laba.

Tujuan utama berdirinya setiap badan usaha memperoleh laba yang sebesarbesarnya. Tanpa diperolehnya laba, suatu perusahaan tidak dapat mengalami pertumbuhan yang terus menerus dan perkembangan usaha. Untuk memperoleh laba tersebut melalui kegiatan penjualan jasa atau pemberian kredit yang menjadi sumber pendapatan utama bagi bank. Semakin besar volume kredit, maka laba yang dihasilkan akan semakin besar.

Ukuran keberhasilan bank dalam memperoleh laba merupakan bagian penting dalam menilai kesehatan keuangan bank. Karena laba yang besar perusahaan mampu berbuat banyak bagi kesejahteraan pemilik, karyawan dan melakukan investasi. Namun laba yang besar belum menunjukkan efesiensi penggunaan modal yang digunakan. Efesiensi bank dalam menghasilkan laba dapat diukur dengan rasio rentabilitas. Rentabilitas merupakan suatu cara untuk mengukur kemampuan bank dalam menghasilkan laba dengan aktiva atau modal dalam periode tertentu. Tingkat rentabilitas mencerminkan kemampuan modal bank dalam menghasilkan keuntungan. Dengan tingkat rentabilitas yang tinggi dapat mencerminkan efesien yang tinggi pula.

Rentabilitas dibedakan menjadi dua macam, yaitu rentabilitas ekonomi dan 
Chairunisa Cipta, Daryoni dan Samsul Anwar

rentabilitas modal sendiri. Rentabilitas ekonomi dapat diketahui dengan membandingkan antara laba usaha dengan modal sendiri dan modal asing, sedangkan rentabilitas modal sendiri merupakan kemampuan perusahaan dengan modal sendiri yang bekerja untuk menghasilkan keuntungan.

Rentabilitas ekonomi menunjukkan efesiensi terhadap penggunaan total aktiva dalam memperoleh laba. Rentabilitas ekonomi diukur dengan membandingkan laba sebelum pajak dengan total aktiva. Semakin tinggi rasio rentabilitas ekonomi berarti kemampuan perusahaan dalam memperoleh laba semakin baik. Dengan semakin besarnya nilai rentabilitas ekonomi menunjukkan adanya efesiensi penggunaan aktiva yang digunakan untuk kegiatan yang produktif guna menghasilkan laba dan menunjukkan pula kondisi kesehatan bank semakin baik.

Rumusan masalah dalam penelitian ini, rentabilitas ekonomi pada PD. BPR PK Arahan belum sesuai stándar industri yaitu 40\%. Dana yang dihimpun oleh bank baik dari masyarakat maupun pihak luar dialokasikan ke dalam berbagai aktiva, baik yang produktif maupun yang tidak produktif. Dana terhimpun tersebut tersebut merupakan hutang yang menjadi kewajiban bank baik dalam jangka pendek, menengah maupun jangka panjang. Bagian terbesar dari penyaluran dana tersebut ke dalam aktiva produktif adalah pinjaman atau kredit. Dengan demikian pengelolaan hutang pada bank memegang peranan penting untuk menopang kegiatan operasionalnya agar mampu memberikan perolehan laba yang maksimal. Efesiensi bank dalam menghasilkan laba dapat diukur dengan rasio rentabilitas. Rentabilitas ekonomi menunjukkan efesiensi terhadap aktiva dalam memperoleh laba.

\section{TINJAUAN PUSTAKA}

\section{Rentabilitas Ekonomi}

Tujuan perusahaan dalam operasinya adalah memperoleh laba sebanyakbanyaknya. Namun laba yang besar belum dapat menjadi suatu ukuran bahwa perusahaan tersebut telah bekerja dengan melakukan efesiensi. Untuk itu agar efesiensi perusahaan dapat diketahui, perlu adanya pengukuran rentabilitas terhadap perusahaan tersebut.

\section{Pengertian Rentabilitas Ekonomi}

Rentabilitas suatu perusahaan menunjukkan perbandingan antara laba dengan aktiva atau modal yang menghasilkan laba. Dengan kata lain rentabilitas adalah berhubungan pendapatan yang diperoleh oleh suatu perusahaan.

Berikut definisi rentabilitas ekonomi menurut para ahli:

Menurut Munawir (2010: 86) menyatakan bahwa rentabilitas ekonomi 
Chairunisa Cipta, Daryono dan Samsul Anwar

menunjukkan kemampuan perusahaan untuk menghasilkan laba selama periode tertentu.

Menurut Bambang Riyanto (2015: 35), menyatakan bahwa rentabilitas ekonomi adalah perbandingan antara laba dengan aktiva atau modal yang menghasilkan laba dengan rumus rentabilitas $=:$ x 100\%, dimana $\mathrm{L}$ adalah laba dan $\mathrm{M}$ adalah aktiva atau modal.

Menurut Frianto Pandia (2012: 64) menyatakan bahwa rentabilitas ekonomi adalah perbandingan laba (sebelum pajak) dengan aktiva yang dimiliki oleh bank pada periode tertentu.

Berdasarkan kedua pendapat diatas maka rentabilitas ekonomi adalah kemampuan perusahaan untuk menghasilkan laba dengan membandingkan laba (sebelum pajak) dengan aktiva yang dimilikinya.

\section{Indikator Rentabilitas Ekonomi}

Dalam penelitian ini yang menjadi indikator variabel rentabilitas Ekonomi (Y) menurut Frianto Pandia (2012: 64) menyatakan bahwa rentabilitas ekonomi adalah perbandingan laba (sebelum pajak) dengan aktiva yang dimiliki oleh bank pada periode tertentu adalah

\section{Ad.1. Laba sebelum pajak}

Keuntungan yang diperoleh oleh perusahaan dalam periode tertentu sebelum dipotong pajak.

Ad.2. Aktiva
Kekayaan perusahaan yang mempunyai manfaat ekonomi di masa mendatang

Faktor yang Mempengaruhi Rentabilitas Ekonomi

Menurut Bambang Riyanto (2015: 36) faktor-faktor yang mempengaruhi rentabilitas ekonomi adalah:

1. Volume penjualan

Salah satu indikator untuk mengetahui kemajuan suatu perusahaan adalah penjualan. Dengan semakin bertambahnya penjualan maka akan menaikan volume pendapatan yang diperoleh perusahaan sehingga biayabiaya akan tertutup juga. Hal ini mendorong perusahaan untuk mengefektifkan modal untuk mengembangkan usahanya.

2.Efisiensi penggunaan biaya

Modal yang diperoleh perusahaan untuk mengembangkan usahanya harus dipelihara dan dipertanggungjawabkan secara terbuka. Dengan kata lain penggunaan modal harus digunakan untuk usaha yang tepat dengan pengeluaran yang hemat sehingga keberhasilan usaha akan tercapai secara tidak langsung pula akan mempengaruhi tingkat rentabilitas.

\section{Profit margin}

Profit margin adalah laba yang diperbandingkan dengan penjualan. Profit margin digunakan untuk mengukur tingkat keuntungan yang dapat dicapai oleh 
Chairunisa Cipta, Daryoni dan Samsul Anwar

perusahaan berkaitan dengan penjualan perusahaan.

4. Struktur modal perusahaan

Struktur modal adalah pembiayaan pembelanjaan permanen perusahaan yang terutama pada hutang jangka panjang, saham preferen dan modal saham biasa, tetapi tidak termasuk hutang jangka pendek.

Komponen Rentabilitas Bank

Menurut Frianto Pandia (2012: 71) menyatakan penilaian rentabilitas pada suatu bank dapat dilakukan terhadap komponen sebagai berikut:

\section{Return on Asset (ROA)}

Return on Asset adalah rasio yang menunjukkan perbandingan laba (sebelum pajak) dengan total aset bank, rasio ini menunjukkan tingkat efesiensi pengelolaan aset yang dilakukan oleh bank yang bersangkutan. ROA merupakan indikator kemampuan perbankan untuk memperoleh laba atas sejumlah aset yang dimiliki bank. Rumus yang digunakan menghitung ROA adalah:

$\mathrm{ROA}=\mathrm{x} 100 \%$

\section{Return on Equity (ROE)}

Return on Equity adalah rasio yang menunjukkan perbandingan antara laba (setelah pajak) dengan modal inti bank, rasio ini menunjukkan tingkat persentase yang dapat dihasilkan. ROE merupakan indikator kemampuan perbankan dalam mengelola modal yang tersedia untuk mendapatkan laba bersih. Rumus yang digunakan menghitung ROE adalah:

$\mathrm{ROE}=\mathrm{x} 100 \%$

\section{Net Interest Margin (NIM)}

Net Interest Margin adalah rasio yang digunakan untuk mengukur kemampuan manajemen bank dalam mengelola aktiva produktifnya untuk menghasilkan pendapatan bunga bersih. Pendapatan bunga bersih diperoleh dari pendapatan bunga dikurangi beban bunga. Semakin besar rasio ini maka meningkatkan pendapatan bunga atas aktiva produktif yang dikelola bank sehingga kemungkinan suau bank dalam kondisi bermasalah semakin kecil. Rumus untuk menghitung NIM adalah:

$\mathrm{NIM}=\mathrm{x} 100 \%$

4. Biaya Operasional Pendapatan Operasional (BOPO)

BOPO merupakan rasio yang sering disebut rasio efesiensi yang digunakan untuk mengukur kemampuan manajemen bank dalam mengendalikan biaya operasional terhadap pendapatan oeprasional. Semakin kecil rasio ini maka semakin efesien biaya operasional yang dikeluarkan bank yang bersangkutan sehingga kemungkinan suatu bank dalam kondisi bermasalah semakin kecil. Rumus untuk menhitung BOPO adalah: $\mathrm{BOPO}=\mathrm{x} 100 \%$

\section{Kredit}

Kata kredit berasal dari bahasa Yunani "Credere" yang berarti kepercayaan. Dari 
Chairunisa Cipta, Daryono dan Samsul Anwar

bahasa Latin "Creditum" yang berarti kepercayaan akan kebenaran. Kredit bagi suatu bank merupakan kegiatan mengalokasikan dananya dalam bentuk pinjaman yang diberikan untuk memperoleh keuntungan.

\section{Pengertian Kredit}

Secara teoritis semakin besar dana yang dapat dihimpun bank, semakin besar kredit yang dapat diberikan dan semakin besar pula kemungkinan memperoleh pendapatan. Namun dana yang berhasil dihimpun dari berbagai sumber dialokasikan ke dalam berbagai harta sesuai skala prioritasnya baik dalam bentuk aktiva yang menghasilkan keuntungan maupun aktiva yang tidak menghasilkan keuntungan. Tujuannya agar bank dapat mencapai tingkat laba yang optimal dengan tetap memelihara likuiditas yang sehat.

Berikut beberapa pengertian kredit menurut para ahli:

Menurut Lukman Dendawijaya (2011:

8) kredit adalah penyediaan uang atau tagihan yang dapat dipersamakan dengan itu, berdasarkan persetujuan atau kesepakatan pinjam meminjam antara bank dengan pihak lain yang mewajibkan pihak peminjam untuk melunasi utangnya setelah jangka waktu tertentu dengan pemberian bunga

Menurut Frianto Pandia (2012: 169) kredit adalah kegiatan bank mengalokasikan dananya dalam bentuk pinjaman yang diberikan untuk memperoleh keuntungan dengan memperhatikan tingkat keamanannya.

Menurut Kasmir (2014: 113) kredit adalah penyediaan uang atau tagihan yang dapat dipersamakan dengan itu, berdasarkan persetujuan atau kesepakatan antara pihak bank dengan pihak lain yang mewajibkan pihak peminjam untuk mengembalikan uang atau tagihan tersebut setelah jangka waktu tertentu dengan imbalan atau bagi hasil.

Dari pengertian diatas dapat dijelaskan bahwa kredit adalah kegiatan bank mengalokasikan dananya dalam bentuk pinjaman dengan penyediaan uang atau tagihan yang dipersamakan dengan itu berdasarkan persetujuan atau kesepakatan pinjam meminjam antara bank dengan pihak lain untuk memperoleh keuntungan dengan memperhatikan tingkat keamanan dan pihak peminjam harus membayar kembali bersama bunganya sesuai perjanjian yang telah disepakati.

\section{Indikator Kredit}

Dalam penelitian ini yang menjadi indikator variabel kredit (X1) menurut Frianto Pandia (2012: 169) menyatakan bahwa kredit adalah kegiatan bank mengalokasikan dananya dalam bentuk pinjaman yang diberikan untuk memperoleh keuntungan dengan memperhatikan tingkat keamanannya adalah.

Tujuan Kredit 
Chairunisa Cipta, Daryoni dan Samsul Anwar

Tujuan suatu fasilitas kredit mempunyai beberapa tujuan yang hendak dicapai yang tentunya tergantung dari tujuan bank itu sendiri. Tujuan pemberian kredit menurut Kasmir (2014: 116) antara lain:

\section{Mencari keuntungan}

Tujuan utama pemberian kredit adalah untuk memperoleh keuntungan. Hasil keuntungan ini diperoleh dalam bentuk bunga yang diterima oleh bank sebagai balas jasa dan biaya administrasi kredit yang dibebankan kepada nasabah.

\section{Membantu usaha nasabah}

Tujuan selanjutnya adalah membantu usaha nasabah yang memerlukan dana, baik dana untuk investasi maupun dana untuk modal kerja. Dengan dana tersebut, maka pihak debitur akan dapat mengembangkan dan memperluaskan usahanya. Dalam hal ini baik bank maupun nasabah sama-sama diuntungkan

\section{Membantu pemerintah}

Tujuan lainnya adalah membantu pemerintah dalam berbagai bidang. Bagi pemerintah semakin banyak kredit yang disalurkan oleh pihak perbankan, maka semkain baik, mengingat semakin banyak kredit berarti adanya kucuran dana dalam rangka peningkatan pembangunan di berbagai sektor, terutama sektor riil.

Keuntungan bagi pemerintah dengan menyalurkan pemberian kredit oleh dunia perbankan adalah:
a.Penerimaan pajak, dari keuntungan yang diperoleh nasabah dan bank

b. Membuka kesempatan kerja, dalam hal ini untuk kredit pembangunan usaha baru atau perluasan usaha akan membutuhkan tenaga kerja baru sehingga dapat menyedot tenaga kerja yang masih menganggur.

c. Meningkatkan jumlah barang dan jasa, jelas sekali bahwa sebagian besar kredit yang disalurkan akan dapat meningkatkan jumlah produksi barang dan jasa yang beredar di masyarakat, sehingga akhirnya masyarakat memiliki banyak pilihan.

d. Menghemat devisa negara, terutama untuk produk-produk yang sebelumnya diimpor dan apabila sudah dapat diproduksi di dalam negeri dengan fasilitas kredit yang ada jelas akan dapat menghemat devisia negara.

e. Meningkatkan devisia negara, apabila produk dari kredit yang dibiayai untuk keperluan ekspor.

Fungsi Kredit

Fungsi kredit menurut Kasmir (2014: 117) adalah sebagai berikut:

1. Untuk meningkatkan daya guna uang

2. Untuk meningkatkan peredaran dan lalu lintas uang

3. Untuk meningkatkan daya guna barang Kredit yang diberikan oleh bank akan dapat digunakan oleh si debitur untuk mengolah barang yang semula tidak berguna menjadi berguna atau bermanfaat.

4. Meningkatkan peredaran barang 
Chairunisa Cipta, Daryono dan Samsul Anwar

5. Sebagai alat stabilitas ekonomi

6. Untuk meningkatkan kegairahan berusaha.

7.Untuk meningkatkan pemerataan pendapatan

8.Untuk meningkatkan hubungan internasional

Analisis Kredit

Analisis kredit atau penilaian kredit adalah suatu proses yang dimaksudkan untuk menganalisis atau menilai suatu permohonan kredit yang diajukan oleh calon debitur kredit sehingga dapat memberikan keyakinan kepada pihak bank bahwa prosyek yang akan dibiayai dengan kredit bank cukup layak (feasible). Analisis kredit berdasarkan princisp "6C" menurut Lukman Dendawijaya (2009: 89) adalah:

\section{Character}

\section{Capital}

\section{Capacity}

Kemampuan nasabah yang diukur meliputi:

a. Kemampuan calon nasabah menyediakan dana untuk pembiayaan

b. Kemampuan calon nasabah untuk membangun proyeknya

c. Kemampuan nasabah untuk menghasilkan produk dari proyeknya

d. Kemampuan nasabah untuk menjual hasil produksinya

e. Kemampuan nasabah untuk memperoleh laba dari penjualan tersebut. f. Kemampuan nasabah untuk menyediakan dana yang memadai untuk membayar kewajiban-kewajibannya kepada bank.

\section{Condition}

Dalam pemberian kredit, kondisi perekonomian harus pula dianalisis (paling sedikit selama jangka waktu kredit), kondisi tersebut meliputi:

a. kondisi dari sekotr industri dimana proek yang akan dibangun

b. ketergantungan terhadap bahan baku yang harus diimpor

c. nilai kurs valuta terhadap nilai uang domestik

d. peraturan-peraturan pemerintah yang berlaku

e. kondisi perekonomian secara nasional, regional dan global

f. kemudahan untuk memperoleh sumber daya (bahan baku dan tenaga kerja)

g. tingkat bunga kredit yang berlaku dan sebagainya

5. Collateral

Fungsi dari agunan tersebut antara lain:

a. bagian dari pelaksanaan prinsip kehatihatian yang dilakukan bank

b. cara yang dilakukan bank untuk mengantisipasi kemungkinan terjadinya kegagalan usaha atau proyek yang dibiayainya

c. cara untuk mendorong nasabah agar mau bersungguh-sungguh dalam 
Chairunisa Cipta, Daryoni dan Samsul Anwar

melaksanakan/mengelola proyeknya yang ikut dibiayai bank

d. pengganti pembayaran apabila nasabah tidak dapat memenuhi kewajibannya kepada bank

\section{Constraints}

\section{Hutang}

Hutang memiliki peranan penting terhadap kelancaran kegiatan operasional perusahaan. Hutang yang dikelola secara optimal akan memberikan kemampuan ekonomi untuk memperoleh keuntungan. Walaupun hutang memiliki resiko terhadap perusahaan, tetapi apabila dikelola secara efektif dan efesien akan memberikan keuntungan serta melunasi kewajibannya untuk membayar hutang tersebut.

Pengertian Hutang

Hutang merupakan modal yang berasal dari luar perusahaan atau modal asing. Hutang diperoleh dari proses pinjaman bank atau lembaga keuangan lainnya. Hutang berfungsi untuk menunjukkan atau mengukur kemampuan perusahaan dalam memenuhi kewajibannya yang sudah jatuh tempo.

Menurut Bambang Riyanto (2011: 214) menyatakan bahwa hutang adalah sumber pembiayaan yang berasal dari luar perusahaan yaitu dari para kreditur dengan beban bunga dan harus dilunasi pada waktu yang telah ditentukan.

Menurut Munawir (2010: menyatakan bahwa hutang adalah semua kwajiban keuangan perusahaan kepada pihak lain yang belum terpenuhi, dimana hutang ini merupakan sumber dana atau modal perusahaan yang berasal dari kreditor. Hutang dapat dibedakan ke dalam hutang lancar (hutang jangka pendek) dan hutang jangka panjang.

Menurut Kasmir (2014: 40) menyatakan bahwa hutang adalah kewajiban perusahaan kepada pihak lain yang harus dibayar.

Dari pendapat di atas penulis menyimpulkan bahwa hutang adalah sumber pembiayaan dari luar perusahaan biasanya dari lembaga keuangan yang akan menjadi kewajiban perusahaan yang harus dibayar kembali dalam waktu yang telah ditentukan. Indikator Hutang

Dalam penelitian ini yang menjadi indikator variabel hutang lancar (X2) menurut Munawir (2010: 18) menyatakan bahwa hutang adalah semua kwajiban keuangan perusahaan kepada pihak lain yang belum terpenuhi, dimana hutang ini merupakan sumber dana atau modal perusahaan yang berasal dari kreditor. Hutang dapat dibedakan ke dalam hutang lancar (hutang jangka pendek) dan hutang jangka panjangadalah:

Ad. 1 Hutang jangka pendek (hutang lancar)

$\begin{array}{ccc}\text { Kewajiban } & \text { keuangan } & \text { yang } \\ \text { pelunasannya atau } & \text { pembayaran } & \text { akan }\end{array}$ 
Chairunisa Cipta, Daryono dan Samsul Anwar

dilakukan dalam jangka pendek (satu tahun) dengan menggunakan aktiva lancar yang dimiliki perusahaan

\section{Ad. 2 Hutang jangka panjang}

Kewajiban keuangan yang jangka waktu pembayarannya (jatuh tempo) lebih dari satu tahun.

\subsubsection{Penggolongan Hutang}

Menurut Munawir (2010: 18) hutang, terbagi dalam tiga golongan, yaitu:

\section{Hutang Jangka Pendek (Short-term debt)}

Hutang lancar atau hutang jangka pendek adalah kewajiban keuangan perusahaan yang perlunasannya atau pembayaran akan dilakukan dalam jangka pendek (satu tahun sejak tanggal neraca) dengan menggunakan aktiva lancar yang dimiliki oleh perusahaan. Sebagian besar hutang jangka pendek terdiri dari kredit perdagangan barang / jasa, yaitu kredit yang diperlukan untuk dapat menyelenggarakan usahanya. Adapun jenisjenis hutang jangka pendek diantaranya adalah:

\section{a. Rekening Koran}

Kredit Rekening Koran adalah kredit yang diberikan oleh Bank kepada perusahaan dengan batas plafond tertentu dimana perusahaan mengambilnya tidak sekaligus melainkan sebagian demi sebagian sesuai dengan kebutuhannya, dan bunga yang dibayar hanya untuk jumlah yang telah diambil saja, meskipun sebenarnya perusahaan meminjamnya lebih dari jumlah tersebut.

3. Hutang Jangka Panjang, (long term debt) Hutang jangka panjang merupakan hutang yang jangka waktunya adalah panjang, umumnya lebih dari 10 tahun. Hutang jangka panjang ini pada umumnya digunakan untuk membelanjai perluasan perusahaan atau modernisasi dari perusahaan dari perusahaan karena kebutuhan modal untuk keperluan tersebut meliputi jumlah yang besar. Adapun bentuk-bentuk utama dari hutang jangka panjang antara lain :

a. Pinjaman Obligasi (Bond Payables).

Pinjaman Obligasi adalah pinjaman uang untuk jangka waktu yang panjang, untuk mana si debitur mengeluarkan surat pengakuan hutang yang mempunyai nominal tertentu. Adapun jenis jenis dari obligasi antara lain adalah:

1) Obligasi biasa (Bond)

2) Obligasi pendapatan (Income Bonds)

3) Obligasi yang dapat di tukarkan (Convertible-bonds)

b. Pinjaman Hipotik (Mortgage)

Pinjaman hipotik merupakan pinjaman jangka panjang dimana pemberi uang (kreditur) diberi hak hipotik terhadap suatu batang tidak bergerak.

\subsubsection{Hutang Lancar}


Chairunisa Cipta, Daryoni dan Samsul Anwar

Menurut Muslich (2007: 134) dari berbagai sumber dana, pembiayaan hutang lancar dapat dikelompokkan dalam:

1.Hutang lancar dengan jaminan, terdiri dari: a. Hutang dagang, merupakan suatu bentuk sumber dana jangka pendek yang umum dimiliki hampir semua perusahaan. Hutang dagang ini timbul karena transaksi pembelian suatu barang disetujui, dan perusahaan penjual setuju bahwa pembelian tersebut dibayar kemudian, maka dikatakan pembeli memperoleh kredit atau sumber dana hutang dagang.

b.Commercial paper, merupakan surat berharga pasar uang yang berjangka pendek, dan merupakan suatu janji dari perusahaan yang mengeluarkannya untuk membayar pada tanggal jatuh waktu. Commercial paper ini umumnya dikeluarkan oleh perusahaan besar yang memiliki kepercayaan dan reputasi yang cukup dikenal luas.

c. Kredit bank, yaitu kredit yang diberikan bank kepada perusahaan semata-mata karena kepercayaan yang diberikan oleh bank kepada penerima kredit.

2.Pinjaman dengan jaminan adalah pemberi kredit meminta barang kebendaan atau tagihan sebagai jaminan atas kreditnya. Pinjaman dengan jaminan terdiri dari :

a.Pledging receiveble, yaitu peminjam menggadaikan piutangnya sebagai jaminan kredit yang diperoleh. b. Factoring receiveble, perusahaan yang menerima kredit dijual kepada faktor, yaitu perusahaan yang mengambil alih piutang ini yang kemudian menagih pembayaran dari piutang-piutang yang dijual.

\subsubsection{Sumber-Sumber Hutang}

Kebijakan perusahaan dalam membiayai kegiatan operasionalnya dapat bersumber dari pembiayaan yang sifatnya jangka pendek ataupun pembiayaan jangka panjang, hal ini tergantung dari tingkat kebutuhan pengembangan usaha perusahaan tersebut.

Menurut Muslich (2007: 134) sumbersumber hutang dapat dikelompokan menjadi:

1. Hutang tanpa jaminan

Semua bentuk sumber hutang yang tidak dijamin dengan kebendaan atau tagihan. Hutang yang diberikan berdasarkan kepercayaan dari pemberi hutang dan kemampuan pembayaran dari pembayar untuk membayar hutangnya.

2. Hutang dengan jaminan

Suatu sumber hutang yang dijamin dengan kebendaan untuk menutup kerugian jika peminjam tidak dapat memenuhi kewajiban. Yang termasuk dari hutang dengan jaminan antara lain kredit bank, anjak piutang dan jaminan piutang pledging.

Hutang dagang merupakan suatu bentuk sumber dana jangka pendek yang umum dimiliki hampir semua perusahaan. Hutang dagang timbul karena transaksi pembelian 
Chairunisa Cipta, Daryono dan Samsul Anwar

suatu barang disetujui dan perusahaan penjual setuju bahwa untuk pembelian tersebut dibayar kemudian, maka dikatakan pembeli memperoleh kredit atau sumber dana hutang dagang.

Pengaruh dan Hubungan Antar Variabel Pengaruh dan Hubungan Hutang Terhadap Kredit

Hutang pada bank identik dengan sumber dana bank itu sendiri, karena sebagian besar sumber dana bank bersumber dari hutang bank terhadap nasabahnya dan merupakan kewajiban yang harus dipenuhi bila dana tersebut ditarik atau jatuh tempo. Untuk itu pengelolaan hutang tersebut memegang peranan penting agar dana yang diperoleh tersebut mampu memberikan pendapatan.

Tujuan utama pemberian kredit adalah untuk memperoleh keuntungan. Hasil keuntungan ini diperoleh dalam bentuk bunga yang diterima oleh bank sebagai balas jasa dan biaya adminsitrasi kredit yang dibebankan kepada nasabah. Keuntungan ini penting untuk kelangsungan hidup bank. Disamping itu keuntungan juga akan memperbesar usaha bank itu sendiri.

Sumber pendapatan bank adalah dengan menyalurkan kredit atau pinjaman kepada nasabah atau masyarakat yang membutuhkan dana untuk keperluan usaha maupun keperluan lainnya. Dalam penyaluran kredit, bank akan menghadapi resiko berkenaan dengan masalah kredit tersebut.
Dalam alokasi dana bank, kredit merupakan bagian terbesar dalam pos neraca keuangan bank. Pemberian kredit ini menjadi bagian aktiva produktif dalam memperoleh keuntungan. Semakin besar dana yang dialokasikan untuk kredit maka akan semakin besarkeuntungan yang diperoleh bank.

Semakin besar kredit yang diberikan oleh pihak bank tentunya akan meningkatkan profitabilitas. Namun apabila kredit yang diberikan mengakibatkan masalah kredit (macet) karena peminjam mengalami kesulitan pelunasan oleh adanya faktor kesengajaan dan atau faktor eksternal di luar kemampuan debitur yang dapat di ukur dari kolektibilitas tentunya akan menurunkan profitabilitas. Oleh karena dalam memberikan kredit, bank harus berhati-hati dalam melakukan analisa kredit agar kolektibilitas kredit yang baik dapat terjaga.

Menurut Frianto Pandia (2012: 21) menyatakan bahwa dana yang berhasil dihimpun bank dari berbagai sumber akan dialokasikan pada aktiva produktif (kredit) untuk memperoleh keuntungan.

Untuk itu bank harus menanamkan dananya pada investasi yang resikonya minim, yang mempunyai tingkat likuiditas relatif tinggi, akan tetapi diharapkan memberikan keuntungan yang optimal. Hal ini dimaksudkan agar bank dapat memenuhi kewajiban terhadap dana masyarakat dan 
Chairunisa Cipta, Daryoni dan Samsul Anwar

memperoleh pendapatan dari dana yang terhimpun tersebut melalui kredit.

Pengaruh dan Hubungan Kredit Terhadap Rentabilitas Ekonomi

Tujuan utama berdirinya setiap badan usaha adalah memperoleh laba sebesar-besarnya. Tanpa diperolehnya laba, suatu perusahaan tidak dapat mengalami pertumbuhan yang terus-menerus dan perkembangan usaha. Untuk memperoleh laba tersebut dilakukan melalui kegiatan pemberian kredit yang menjadi sumber pendapatan utama bagi bank. Semakin besar volumen kredit, maka laba yang diperoleh semakin akan besar. Hasil keuntungan dari kredit tersebut diperoleh dalam bentuk bunga yang diterima oleh bank sebagai balas jasa dan biaya admisnistrasi kredit yang dibebankan terhadap nasabah. Keuntungan ini penting untuk kelangsungan hidup bank. Disamping itu keuntungan juga akan memberbesar usaha bank itu sendiri.

Dalam alokasi dana bank, kredit merupakan bagian terbesar dalam pos neraca keuangan bank. Pemberian kredit ini menjadi bagian aktiva produktif dalam memperoleh keuntungan. Semakin besar dana yang dialokasikan untuk kredit maka akan semakin besar keuntungan yang diperoleh.

Menurut Kasmir (2015: 126) agar keuntungan bank optimal, maka jumlah kredit yang disalurkan haruslah sesuai dengan target yang ditetapkan. Karena kualitas kredit berkaitan dengan risiko kemacetan suatu kredit yang disalurkan, makin berkualitas kredit yang diberikan, maka akan memperkecil resiko terhadap kemungkinan kredit tersebut macet atau bermasalah.

Keuntungan yang besar bagi bank bukan merupakan ukuran bahwa bank telah bekerja secara efesien. Ukuran keberhasilan bank dalam memperoleh laba merupakan bagian penting dalam menilai kesehatan bank. Karena laba yang besar mampu melakukan banyak bagi kesejahteraan pemilik, karyawan dan melakukan investasi. Namun laba yang besar belum menunjukan efisiensi penggunaan modal yang digunakan. Efesiensi bank dalam memperoleh keuntungan dapat diperoleh melalui rasio rentabilitas ekonomi. Rentabilitas ekonomi dapat dihitung dengan membandingkan laba sebelum pajak dengan total aktiva yang dimiliki pada periode tersebut.

\section{Kerangka Pemikiran}

Setiap perusahaan membutuhkan dana untuk membiayai seluruh kegiatan operasionalnya. Dana untuk membiayai operasi bank dapat diperoleh dari berbagai sumber. Perolehan dana ini tergantung bank itu sendiri apakah menghimpun dana titipan masyarakat satau dari lembaga keuangan lainnya. Kemampuan bank memperoleh sumber-sumber dana yang 
Chairunisa Cipta, Daryono dan Samsul Anwar

diinginkan sangat mempengaruhi kelanjutan usaha bank. Dalam mencari sumber-sumber dana bank harus mempertimbangkan kemudahan memperolehnya, jangka waktu serta biaya yang harus dikeluarkan untuk mendapatkan dana tersebut.

Menurut Bambang Riyanto (2015: 214) hutang adalah sumber pembiayaan yang berasal dari luar perusahaan yaitu dari para kreditur dengan beban bunga dan harus dilunasi pada waktu yang telah ditentukan, yang biasanya jangka waktu tidak lebih dari 1 tahun.

Dalam kegiatan operasional, bank menghimpun dana dari masyarakat dan menyalurkan kembali kepada masyarakat dengan mengalokasikan dalam bentuk kredit. Kredit merupakan pemberian pinjaman sejumlah uang dari suatu pihak (lembaga keuangan, seseorang atau perusahaan) kepada pihak lain (seseorang atau perusahaan) yang mewajibkan peminjamnya untuk melunasi dalam jangka waktu tertentu dengan jumlah bunga yang disepakati bersama.

Dari kredit yang diberikan bank akan memperoleh pendapatan dalam bentuk provisi dan bunga atau pembagian keuntungan. Selain itu kredit yang diberikan oleh bank mengandung suatu risiko kredit. Risiko kredit tersebut terbagi ke dalam kredit lancar, kurang lancar, diragukan, dan macet. Risiko kredit tersebut sering disebut kredit bermasalah. Untuk itu dalam pemberian kredit perlu dilakukan analisa kredit terhadap calon peminjam dalam menetapkan besarnya kredit yang akan diberikan.

Menurut Kasmir (2014: 115) dalam pemberian kredit terdapat unsur resiko akibat adanya tenggang waktu, maka pengembalian kredit akan memungkinkan suatu resiko tidak tertagihnya atau macet pemberian kredit. Semakin panjang suatu kredit, maka semakin besar pula resikonya, demikian pula sebaliknya.

Kegiatan bank dalam pemberian kredit diperuntukan untuk menghasilkan laba. Besarnya laba yang diperoleh belum menunjukkan sebagai indikator mengenai efisiensi penggunaan modal. Untuk mengukur efisiensi bank berdasar pada besarnya laba kurang tepat, sebab laba yang besar tidak selalu mencerminkan tingkat rentabilitas yang tinggi. Rentabilitas yang tinggi selain mencerminkan tingkat kesehatan bank juga mencerminkan efesiensi pengelolaan keuangan dalam memperoleh laba dengan modal sendiri yang digunakan. Bagi manajemen, rentabilitas ekonomi yang tinggi harus menjadi tujuan dalam melakukan efesiensi terhadap penggunaan aktiva dalam memperoleh laba.

Menurut Frianto Pandia (2012: 71) menyatakan bahwa rentabilitas adalah rasio yang menunjukkan perbandingan antara laba 
Chairunisa Cipta, Daryoni dan Samsul Anwar

sebelum pajak dengan aktiva yang dimiliki bank.

Berdasarkan pemikiran tersebut dapat disimpulkan bahwa pada umumnya masalah rentabilitas ekonomi adalah lebih penting dari pada masalah laba, karena laba yang besar belum merupakan ukuran efisiensi. Efisien baru dapat diketahui dengan membandingkan laba yang diperoleh dengan kekayaan atau modal yang menghasilkan laba tersebut atau dengan kata lainnya ialah menghitung rentabilitas ekonomi.

Berdasarkan uraian kerangka pemikiran diatas, maka peneliti membuat desain penelitian sebagai berikut :

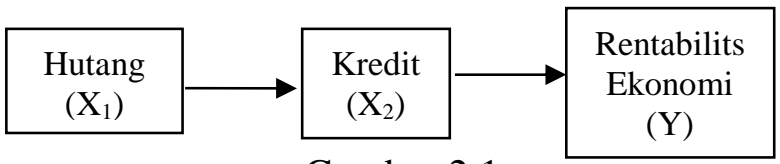

Gambar 2.1

Kerangka Pemikiran

\subsection{Hipotesis}

Berdasarkan kerangka pemikiran yang telah diuraikan maka, hipotesis penelitian tersebut dapat dinyatakan sebagai berikut:

1. Diduga adanya pengaruh hutang terhadap kredit

2. Diduga adanya pengaruh kredit terhadap rentabilitas ekonomi

\section{METODOLOGI PENELITIAN}

Jenis penelitian dalam skripsi ini adalah jenis penelitian Kuantitatif. Penelitian Kuantitatif adalah jenis penelitian dengan menggunakan data sekunder atau data time series. Data sekunder dalam penelitian inia adalah data yang diperoleh dari hasil Publikasi Badan Pusat Statistik, pada web resmi (www.bps.go.id), hasil publikasi dari Bank Indonesia (www.bi.go.id), dan Investasi Asing Langsung dari hasil Publikasi dari Badan Koordinasi Penanaman Modal (www.bkpm.go.id).

Tehnik yang digunakan dalam pengumpulan data adalah dengan dokumentasi setiap triwulan pada Badan Pusat Statistik yang dipublikasi melalui www.bps.go.id, Bank Indonesia yang dipublikasi melalui www.bi.go.id dan Badan Koordinasi Penanaman Modal yang dipublikasi melalui www.bkpm.go.id.

Penelitian ini menggunakan tekhnik analisi linear berganda yang digunakan untuk memprediksi pengaruh Pertumbuhan Ekonomi dan BI rate terhadap Investasi Asing Langsung.

\section{PEMBAHASAN}

Pengaruh Pertumbuhan Ekonomi terhadap Investasi Asing Langsung Berdasarkan Uji Asumsi Klasik Pengujian terhadap asumsi klasik yang akan dilakukan meliputi Multikolinieritas, Autokorelasi, Normalitas, Linieritas, dan

\section{Heterokedastisitas}

Multikolinieritas

\section{Tabel 4.1}


Chairunisa Cipta, Daryono dan Samsul Anwar

UJi Multikolinieritas

\begin{tabular}{llll}
\hline \multicolumn{3}{c}{ Coefficient } & \multicolumn{2}{l}{ Uncentered } & Centered \\
Variable & Variance & VIF & VIF \\
\hline PDB & $1.09 \mathrm{E}-06$ & 19.96749 & 1.095590 \\
BIRATE & $3.77 \mathrm{E}+15$ & 43.90837 & 1.095590 \\
$\mathrm{C}$ & $2.83 \mathrm{E}+13$ & 79.47683 & NA \\
\hline
\end{tabular}

Sumber: Ouput Eviews 9 (2018)

Hasil uji Multikolinieritas, dapat dilihat pada tabel Centeed VIF. Nilai VIF untuk Variabel PDB dan BI RATE sama-sama 1,0955 Karena nilai VIF dari kedua variabel tidak ada yang lebih besar dari 10 ata 5 maka dapat dikatakan tidak terjadi multikolinieritas pada kedua variabel bebas tersebut.

AutoKorelasi

Tabel 4.2

Uji Autokorelasi

Breusch-Godfrey Serial Correlation LM Test: $\mathrm{du}<\mathrm{dw}<4-\mathrm{du} \quad$ yaitu

$1,5736<$

$1,900667<2,0993$ yang artinya H0 diterima yang artinya tidak terjadi autokorelasi.

Normalitas

Grafik 4.1

Uji Normalitas

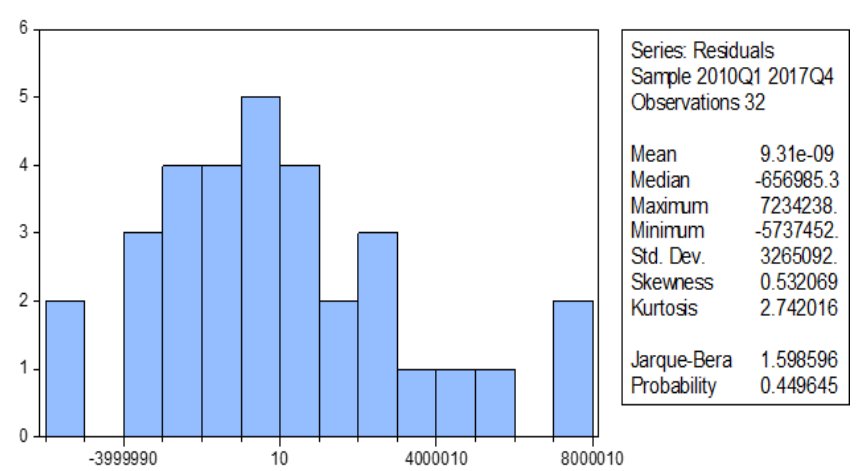

Sumber: Ouput Eviews 9 (2018)

Nilai Probabilitas Jarque-Bera hitung sebesar $0,449>0,05$ sehingga dapat F-statistic $\quad 1.736397$ Prob. $\mathrm{F}(2,27) \quad 0.1953$ disimpulkan bahwa residual terdistribusi Obs*R-squared 3.646841 Prob. Chi-Square(2) 0.1615

Sumber: Ouput Eviews 9 (2018)

Pada penelitian ini menunjukan nilai Probabilitas F statistic $(2,27)$ sebesar 0,19> 0,05 maka hipotesis menyatakan bahwa serial korelasi diterima. Selain menggunakan LMtest, penelitian ini menggunakan Durbin Watson hasil pengujian korelasi diperoleh nilai Durbin Watson sebesar 1.900667. Berdasarkan tabel Durbin Watson, dengan jumlah sample $(n)=32$ dan jumlah variabel bebas $(\mathrm{k})=2$ diperoleh nilai $\mathrm{dl}=1,3093$ dan $\mathrm{du}=1,5736$ sehingga dapat ditentukan bahwa durbin watson hitung terletak pada daerah tidak ada autokorelasi atau memenuhi kriteria normal yang artinya asumsi klasik

Linieritas

Tabel 4.3

Uji Linieritas

Ramsey RESET Test

Equation: UNTITLED

Specification: PMA PDB BIRATE C

Omitted Variables: Squares of fitted values

\begin{tabular}{llll}
\hline \hline & Value & Df & Probability \\
\cline { 2 - 3 } t-statistic & 0.79219528 & 0.4349 \\
F-statistic & $0.627573(1,28)$ & 0.4349 \\
Likelihood ratio & $0.709307 \quad 1$ & 0.3997 \\
\hline \hline
\end{tabular}

Sumber: Ouput Eviews 9 (2018)

Pada kasus ini nilai nya $0,43>0,05$ sehingga dapat disimpulkan bahwa hipotesis yang menyatakan bahwa model linear diterima. 
Heterokedastisitas

Tabel 4.4

UJi Heterokedastisitas

Heteroskedasticity Test BreuschPagan-Godfrey

$\begin{array}{llll}\text { F-statistic } & 0.454402 & \text { Prob. F(229) } & 0.6393\end{array}$

Obs*R-squared $0.972346 \quad$ Prob.Chi-Square(2) 0.6150

Scaled ex plained SS 0.695j67 Prob. Chi-Square(2) 0.7063

Sumber: Ouput Eviews 9 (2018)

Nilai Probabilitas F hitung sebesar 0,63 $>0,05$ sehingga berdasarkan uji hipotesis, $\mathrm{H} 0$ diterima yang artinya tidak terjadi heterokedastisitas.

Berdasarkan hasil analisis linear berganda nilai koefesien Pertumbuhan Ekonomi adalah 0,04 maka dapat disimpulkan bahwa Pertumbuhan Ekonomi berpengaruh signifikan terhadap Investasi Asing Langsung. Dengan demikian hipotesis yang mengatakan bahwa Pertumbuhan Ekonomi berpengaruh signifikan terhadap Investasi Asing Langsung (H1) diterima. Berdasarkan hasil yang didapat dari uji t, nilai Probabilitas untuk Pertumbuhan Ekonomi adalah 0,00>0,05 yang berarti Pertumbuhan Ekonomi berpengaruh signifikan terhadap Investasi Asing Langsung.

Hasil penelitian ini mendukung hasil penelitian terdahulu yang dilakukan oleh Tania melinda Dewi (2016) dan Jonny Abdune (2013) yang mengatakan bahwa GDP berepengaruh positif signifikan terhadap Investasi Asing Lansgung. Pada
Chairunisa Cipta, Daryoni dan Samsul Anwar Penelitian ini Pertumbuhan Ekonomi juga menunjukan pengaruh postif signifikan terhadap Investasi Asing Langsung di Indonesia tahun 2010-2017.

Pengaruh BI rate terhadap Investasi Asing Langsung Pengaruh Pertumbuhan Ekonomi terhadap Investasi Asing Langsung

Berdasarkan hasil analisis linear berganda nilai koefesien BI rate adalah 0,56 maka dapat disimpulkan bahwa BI rate tidak berpengaruh signifikan terhadap Investasi Asing Langsung. Dengan demikian hipotesis yang mengatakan bahwa Pertumbuhan Ekonomi berpengaruh signifikan terhadap Investasi Asing Langsung (H1) ditolak. Berdasarkan hasil yang didapat dari uji t, nilai Probabilitas untuk Pertumbuhan Ekonomi adalah 0,35>0,05 yang berarti BI rate tidak berpengaruh signifikan terhadap Investasi Asing Langsung.

Hasil penelitian ini mendukung hasil penelitian terdahulu yang dilakukan oleh Putu Kartika Dewi (2015) yang mengatakan bahwa BI rate tidak berepengaruh positif signifikan terhadap Investasi Asing Lansgung. Pada Penelitian ini BI rate juga menunjukan tidak berpengaruh signifikan terhadap Investasi Asing Langsung di Indonesia tahun 2010-2017.

Hasil penelitian ini ternyata tidak sama dengan Tania Melinda Dewi dan Hendy Cahyono (2016) dan Jonny Abdune (2013) menyimpulkan bahwa tingkat BI rate tidak 
Chairunisa Cipta, Daryono dan Samsul Anwar

berpengaruh terhadap Investasi Asing Langsung. Menurut Putu Kartika Dewi (2015) menjelaskan Sukuiibunga berpengaruhiinegatif signifikaniiterhadap investasiiiasing langsung. Jadi ketika Semakin tinggi BI rate yang berlaku di suatu negara maka semakinkecil keinginan investor untuk menanamkan modalnya, karena Investor tidak akan mendapatkan return yang diharapkan.

\section{KESIMPULAN}

Berdasrkan hasil pengujian dari pembahasan tentang Pengaruh Pertumbuhan Ekonomi dan BI rate Terhadap Investasi Asing Langsung di Indonesia tahun 20102017 maka diperoleh kesimpulan sebagai berikut:

1.Pertumbuhan Ekonomi selama kurun waktu penelitian berpengaruh signifikan terhadap Investasi Asing Langsung. Karena semakin tinggi tingkat pertumbuhan ekonomi di suatu negara maka semakin tinggi pula minat investor asing untuk menanamkan modalnya, sehingga investor akan memperoleh return yang diharapkan.

2.BI Rate selama kurun waktu penelitian tidak berpengaruh signifikan terhadap Investasi Asing langsung. Jadi jika BI rate Mengalami kenaikan maka Investor asing akan semakin kecil untuk menanamkan modalnay di indonesia, karena Investor tidak akan mendapatkan return yang diharapkan.

\section{DAFTAR PUSTAKA}

Abdune, J. (2013). Pengaruh domestic product, nilai tukar, suku bunga, dan inflasi terhadap penanaman modal asing di indonesia. Jurnal Airlangga university.

Azam, M. (2008). Determinants of foreign Direct Invesment in india, indonesia, pakistan. A Quantitative approach.

Baskara, Y. (2017). Pengaruh Faktor Fundamental Makro Ekonomi terhadap Keputusan Investasi Saham Asing di Indonesia tahun 2007-2014. Jurnal Administrasi Bisnis, Vol 47 No.1.

Dewi, P. K. (2015). Pengaruh pertumbuhan ekonomi, suku bunga dan pajak terhadap investasi asing langsung. Ejurnal Manajemen Unud, Vol 4 No 4, 866-878.

Dewi, S. (2013). The Determinant of Foreign Direct Invesment And Their Impact on Growth: Panel Data Analysis for AMU Countries. Journal Internasional Journal of Innovation and Applied Studies, 300-313.

Eliza, M. (2013). Analisis pengaruh Makro Ekonomi terhadap Investasi Asing Langsung di Indonesia. Jurnal Malang. Fadilah, M. A. (2017). Analisis Produk Domestik Bruto, Suku bunga BI rate dan Inflasi terhadap Investasi Asing 
Chairunisa Cipta, Daryoni dan Samsul Anwar

Langsung Tahun 2006-2015. Jurnal Jom Vekom, Vol 4 No.1.

Fahmi, I. (2011). Teori Portofolio dan Analisis Investasi. Bandung: Alfabeta.

G. Jayachandra. (2010). A causal Relationship between Trade, Foreign Direct Invesment and Eonomic Growth for India. Journal Internasional Research of Finance and Economic.

Ginting. (2008). Pembangunan manusis di indonesia dan faktor-faktor yang mempengaruhinya. jurnal perencanaan \& pengembangan wilayah, Vol 4 No 1 , 113-122.

Insah, B. (2013, April). Foreign Direct invesment Inflows and Economic in Ghana. journal internasional of rconomic practices and theories, Vol 3 No 2.

Leitao, N. C. (2010). Foreign Direct Invesment: The Canadian Experience Internasional. Journal Internasional of Economics and Finance, Vol 2 No 4.

Malik, A. (2017, Januari). Pengaruh utang luar negeri dan penanaman modal asing terhadap pertumbuhan ekonomi. Jurnal akuntansi, Vol 3 No 2.

Melinda, T. (2016). Pengaruh Pertumbungan Ekonomi, Bi rate dan Inflasi terhadap Investasi Asing Langsung di Indonesia. Jurnal Pendidikan Ekonomi, 4 No 3.

Rizalatul Isa, Ronny Malavia Mardani, \& Afi Rahmad Slamet. (2016). Pengaruh
Tingkat Suku Bunga Deposito Bank Konvensional, Bagi Hasil, Likuiditas, PDB, terhadap Jumlah Penghimpunan Dana Pihak Ketiga Deposito Mudaharabah Bank Umum Syari'ah yang terdaftar di BI periode 20132016. Jurnal Riset Manangemen.

Rizky, R. L. (2016, Maret). Pengaruh penanaman modal asing, penanaman modal dalam negeri terhadap pertumbuhan ekonomi. jurnal JESP, Vol 8 No 1.

Salim. (2008). Hukum Investasi di Indonesia. Jakarta: Grafindo.

Sarwedi. (2002). Investasi Asing Langsung di Indonesia dan Faktor yang mempengaruhinya. Jurnal Akuntansi dan Keuangan, 17-35.

Seftifany, A. T., Hidayat, R. R., \& Sulasmiyati, S. (2015, Agustus). Analisis Pengaruh Inflasi, Tingkat Suku Bunga, Nilai Tukar Rupiah dan Cadangan Devisa Terhadap Penanaman Modal Asing di Indonesia. Jurnal Administrasi Bisnis (JAB), Vol. 25 No. 2.

Shah, N. (2013). Determinant of Foreign Direct Invesment: A Studi On Banglades. Journal of Economics and Sustainable Development, Vol 4 No 18, 11-19. 
Chairunisa Cipta, Daryono dan Samsul Anwar

Soemitro, R. (2016). Dasar-dasar Hukum Pajak dan Pajak Pendapatan 1994. Bandung: PT. Eresco.

Sondakh, T. R. (2009). Implementasi Prinsip Trasparansi dalam Praktik Penanman modal di indonesia. Malang: Bayu media.

Soumia, Z., \& Abderrezzak, B. (2013, Maret). The Determinants of Foreign Direct Invesment and their Impact on Growth: Panel data Analysis for AMU Countries. Journal Internasional of Innovation and Applied Studies, Vol 2 No 3, 300-313.
Sugiono. (2011). Metode penelitian pendidikan (pendekatan kuantitatif, kualitatif, dan R\&D. Bandung: Alfabeta.

Sukirno. (2011; 9). Ekonomi Pembangunan. Sutrisno, S. (2008). Hukum Investasi Di Indonesia. Jakarta: Grafindo Persada.

Uwubanmwen, E. (2012). The Determinant and Impact of Foreign Direct Invesment in Nigeria. International Journal of Bussines and Management, 7 No 2.

Zaenuddin, m. (2009). Analisis FaktorFaktor yang mempengaruhi PMA di Batam. Jurnal Jejak, 156-166. 